Krzysztof Olszewski, Elwira Żmudzka

\title{
VARIABILITY OF THE VEGETATIVE PERIOD IN POLAND
}

Vegetation of plants depends upon a whole set of mutually linked components of the environment. Climatic conditions for agricultural production are primarily defined through thermal relations, which are, side by side with precipitation, the fundamental factors conditioning the growth of plants.

Thermal relations can be defined with regard to agricultural purposes with the help of a variety of indicators. These include, in particular, the dates of the beginning and end and the duration lengths of the selected thermal periods essential for the development and productivity of plants. In the recent years attempts have been made of introducing corrections into the assessment of the vegetative period, determined on the basis of air temperature, with the help of the phytophenological data (Starkel, 1991), as well as attempts of using remote sensing for mapping and evaluation of the plant condition in connection with the meteorological situations (Bochenek, 1999; Dąbrowska-Zielińska, 1999).

The purpose of the work here reported was to analyse the variability of the vegetative period in Poland in time and space. The paper refers to the notion of meteorological (thermal) vegetative period, introduced by the Polish climatologist, R. Merecki (1914), this notion being identified with the period during which plants can grow. This is the season of the year with the average daily air temperature of at least $5^{\circ} \mathrm{C}$.

The present note makes use of the average monthly values of air temperature from the period 1931-1998 measured at nine weather stations of the Institute of Meteorology and Water Management, the nine stations representing areas with different geographical conditions (Table 1). These data served to determine the dates of the beginning and end, and the duration of the growing season in the consecutive years of the 68-year period analysed. The dates when the threshold value of $5^{\circ} \mathrm{C}$ was crossed were calculated using the method of Gumiński (1950).

\section{BEGINNING OF THE VEGETATIVE PERIOD}

The calculated dates of the beginning of the growing season confirm the regularities known from literature, concerning spatial distribution of this characteristic within the area of Poland (Radomski, 1979), see Table 1. 
Table 1 .

The average and the extreme dates of the beginning of the vegetative period (1931-1998)

\begin{tabular}{|c|c|c|c|}
\hline Locality & Average & Earliest & Latest \\
\hline Szczecin & March $25^{\text {th }}$ & January $29^{\text {th }} 1990$ & April $16^{\text {th }} 1956$ \\
\hline Suwałki & April $11^{\text {th }}$ & March $18^{\text {th }} 1990$ & April $25^{\text {th }} 1941 \& 1955$ \\
\hline Gorzów Wielkopolski & March $25^{\text {th }}$ & February $8^{\text {th }} 1990$ & April $17^{\text {th }} 1956$ \\
\hline Łódź & March $31^{\text {st }}$ & February $22^{\text {nd }} 1990$ & April $18^{\text {th }} 1933$ \\
\hline Siedlce & April $3^{\text {rd }}$ & February $27^{\text {th }} 1990$ & April $20^{\text {th }} 1933 \& 1955$ \\
\hline Wroclaw & March $24^{\text {th }}$ & February $9^{\text {th }} 1990$ & April $13^{\text {th }} 1958$ \\
\hline Kielce & April $2^{\text {nd }}$ & March $10^{\text {th }} 1990$ & April $19^{\text {th }} 1955$ \\
\hline Tomaszów Lubelski & April $4^{\text {th }}$ & March $8^{\text {th }} 1990$ & April $20^{\text {th }} 1933$ \\
\hline Zakopane & April $16^{\text {th }}$ & March $24^{\text {th }} 1934$ & May $4^{\text {th }} 1980$ \\
\hline
\end{tabular}

The growing season in the lowland part of Poland starts on the average at the turn of April, in western Poland at the earliest (in Wrocław on March $24^{\text {th }}$, in Szczecin and Gorzów Wielkopolski on March $25^{\text {th }}$ ), and in northeastern Poland at the latest (Suwałki - April $11^{\text {th }}$ ).

The central and the south-eastern regions are characterised by the starting dates of the growing season in the first days of April (Siedlce - April $3^{\text {rd }}$, Tomaszów - April $4^{\text {th}}$ ). The different conditions for the plant growth and development, which exist in mountain areas cause the starting date of the growing season to be delayed, on the average, until the middle of April (Zakopane - April $16^{\text {th }}$ ). The distribution of dates of the beginning of the growing season indicates that the further to the East the more vegetation is delayed with respect to the western part of the country. The differences in the appearance of the growing season attain more than a dozen days. This confirms the fact known from the literature, namely that the growing season "enters" the lowland part of Poland from the West.

During the period considered, stretching over 68 years, the dates of the beginning of the vegetative period in the Polish plains varied from January $29^{\text {th }}$ (Szczecin - 1990) to April 25 ${ }^{\text {th }}$ (Suwałki - 1941, 1955), so that the extreme delay of the start of vegetative period in the eastern part of Poland with respect to the western part attained even up to 86 days (Fig. 1). In the mountainous areas, represented in the study by the weather station in Zakopane, the earliest start of the growing season occurred in 1934 - on March $24^{\text {th }}$, while the latest - in 1980 - on May $4^{\text {th }}$. Hence, in the exceptional situations the delay of vegetation in mountains in relation to the western part of the country may amount to almost four months (the average values yielding the difference of 22 days). Altogether, on the territory of Poland the growing season can start at the end of January at the earliest and in the first days of May at the latest.

The biggest deviations from the long-term averages towards the earlier start of the growing season occur in western Poland - with the maximum of up to 55 days (the mentioned case of Szczecin in 1990). In eastern Poland they reach in the extreme cases some 20-30 days (Suwałki in 1990-24 days, Tomaszów Lubelski in $1990-27$ days). 

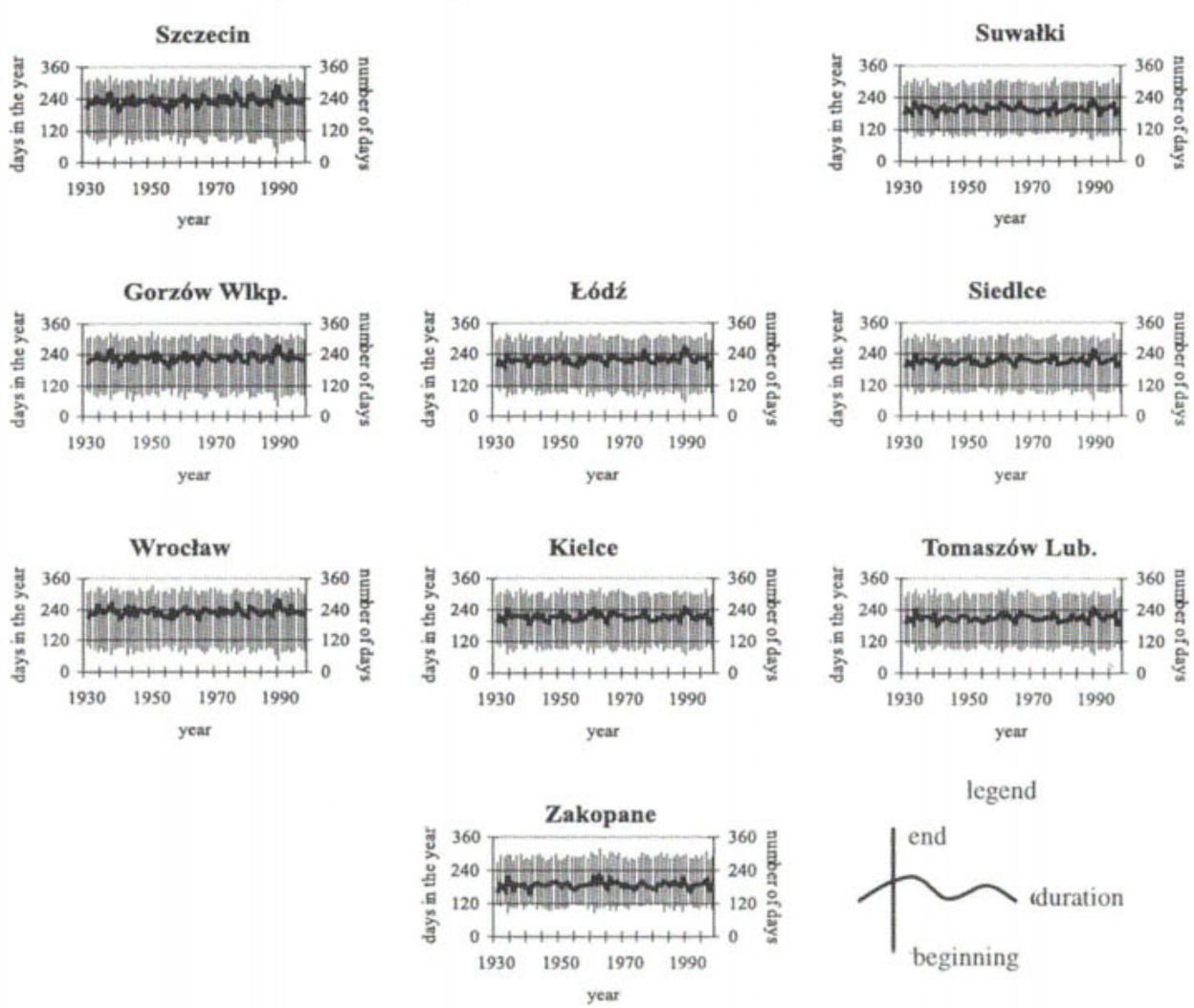

Fig. 1. Changes of the dates of the beginning and end as well as the lengths of the vegetative period in Poland (1931-1998).

The above instances allow to state that the western part of Poland is characterised by the larger range of changes in the starting dates of the vegetative period than the eastern part. The amplitude of fluctuations varies from 77 days in the north-western Poland (Szczecin) down to 38 days in the north-east (Suwałki). The range of changes in the mountains amounts to 41 days.

The element of dynamism in the considerations concerning the proper conditions for the growth of plants is brought into the study by the analysis of frequency with which particular dates appear. Thus, the appropriate time series were established for the five-day periods ("pentades"), since this length of the time intervals reflects the best the distribution of respective frequencies (see Fig. 2).

The analysis of these series allows to state that the starting dates of the growing season in western Poland are most differentiated. Towards the East this differentiation decreases. Likewise, the bracket in which the dominating values are contained changes as well. In western, central and south-eastern Poland the starting point of the vegetative period occurs most often in the 


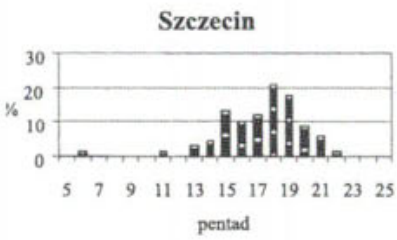

Gorzów Wlkp.

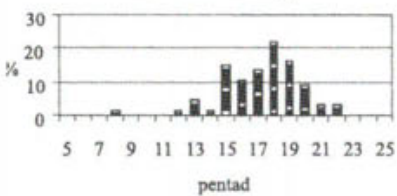

Wrocław

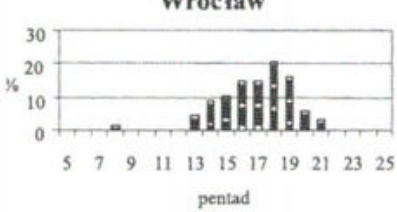

pentad
Eodź

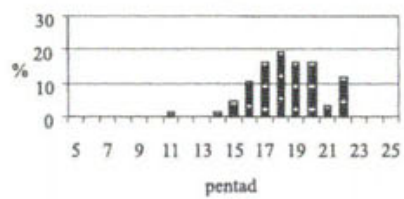

Kielce

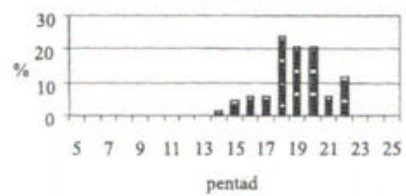

Zakopane

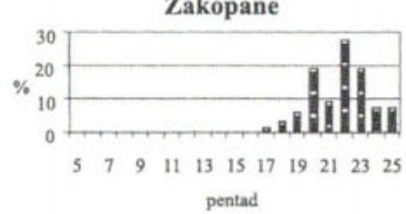

Suwałki

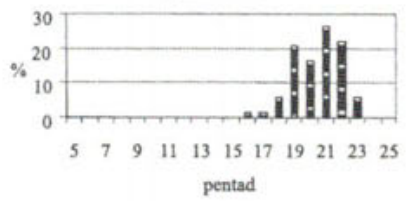

Siedlce

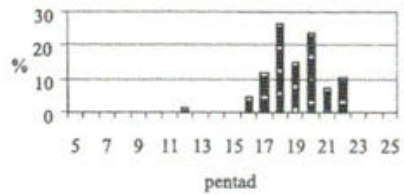

Tomaszów Lub.

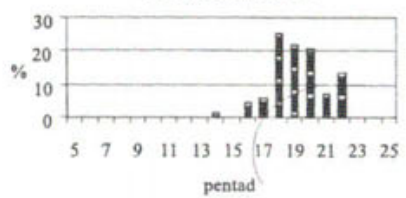

Fig. 2. Frequency $(\%)$ of the dates of the beginning of the vegetative period in the five-day intervals (1931-1998).

$18^{\text {th }}$ pentade of the year (March $27^{\text {th }}-31^{\text {st }}$ ), in north-eastern Poland this takes place in the $21^{\text {st }}$ pentade (April $10^{\text {th }}-15^{\text {th }}$ ), while in the mountains - in the $22^{\text {nd }}$ pentade (April $16^{\text {th }}-20^{\text {th }}$ ).

In the 68-year period considered the dates of the beginning of the vegetative period in Polish plains range between the $6^{\text {th }}$ pentade (January $26^{\text {th }}$ $30^{\text {th }}$ ) and the $23^{\text {rd }}$ pentade (April $21^{\text {st }}-25^{\text {th }}$ ), while in the mountains between the $17^{\text {th }}$ (April 22 ${ }^{\text {nd }}-26^{\text {th }}$ ) and the $25^{\text {th }}$ (May $1^{\text {st }}-5^{\text {th }}$ ) pentade. In Wrocław the growing season does not start before the $8^{\text {th }}$ pentade (February $5^{\text {th }}-9^{\text {th }}$ ), while in Suwałki - not before the $16^{\text {th }}$ pentade (March $17^{\text {th }}-21^{\text {st }}$ ).

The periodicity of changes of the starting dates of the vegetative period was analysed with application of the method of "regression sinusoids" (Boryczka, 1993), consisting in approximation of the chronological data series by the consecutive sinusoids, like below, through minimisation of the rest variance:

$$
y=a_{0}+b \cdot \sin (2 \pi t / \Theta+c)
$$

where: $a_{0}$ - constant, $b$ - amplitude, $\Theta-$ period, $t$ - time in years, $c$ - phase. 
The oscillation spectra determined contain usually up to three statistically significant cycles. Special attention, in view of the largest amplitude, ought to be paid to the cycle of approximately 7.7 years. It is not pronounced only in the mountainous areas. The true length of this cycle is getting bigger as we move from the West (7.6 years) to the East ( 7.9 years in the south-eastern part of Poland). Another short cycle, which is clearly pronounced in the spectrum of oscillations of the starting dates of the vegetative period in the whole of Poland is the 5.6-year cycle (5.5 years in the East of Poland, 5.7 years in the West). The specific character of the mountain areas is expressed through a somewhat different nature of the spectrum of oscillations of the starting dates of the vegetative period. There, the strongest cycles are those with the periods between 10 and 20 years (12.6 years and 19.9 years in Zakopane).

\section{END OF THE VEGETATIVE PERIOD}

The end of the vegetative period in the lowland Poland takes place at the turn of November (Table 2). This occurs in the north-eastern Poland at the earliest (Suwalki - October $25^{\text {th }}$ ), and at the latest in the West of Poland (Szczecin - November $10^{\text {th }}$, Wroclaw - November $9^{\text {th }}$ ). In the south-eastern region vegetation discontinues in the last days of October (Tomaszów Lubelski - October $30^{\text {th }}$ ), while in the central region - in the first decade of November (Łódź - November $3^{\text {rd }}$ ). Again, the specific conditions existing in the mountains - an early onset of winter and absence of thermal summer cause that the growing season ends here very early, already at the beginning of the second decade of October (Zakopane - October $20^{\text {th }}$ ).

Table 2.

The average and the extreme dates of the end of the vegetative period (1931-1998)

\begin{tabular}{|l|l|l|l|}
\hline \multicolumn{1}{|c|}{ Locality } & \multicolumn{1}{|c|}{ Average } & \multicolumn{1}{c|}{ Earliest } & \multicolumn{1}{c|}{ Latest } \\
\hline Szczecin & November $10^{\text {th }}$ & October $26^{\text {th }} 1941$ & December $2^{\text {nd }} 1951$ \\
Suwalki & October 25 & October $9^{\text {th }} 1946 \& 1976$ & November $15^{\text {th }} 1978$ \\
Gorzów Wielkopolski & November $7^{\text {th }}$ & October $25^{\text {th }} 1941,1946,1965$ & November $28^{\text {th }} 1951$ \\
Lódz & November $3^{\text {rd }}$ & October $13^{\text {th }} 1946$ & November $23^{\text {rd }} 1951$ \\
Siedlce & October $31^{\text {st }}$ & October $12^{\text {th }} 1946$ & November $18^{\text {th }} 1996$ \\
Wroclaw & November $9^{\text {th }}$ & October $21^{\text {st }} 1946$ & November $29^{\text {th }} 1951$ \\
Kielce & October $31^{\text {st }}$ & October $10^{\text {th }} 1946$ & November $21^{\text {st }} 1951$ \\
Tomaszów Lubelski & October $30^{\text {th }}$ & October $10^{\text {th }} 1946$ & November $18^{\text {th }} 1963$ \\
Zakopane & October $20^{\text {th }}$ & September $29^{\text {th }} 1931$ & November $17^{\text {th }} 1963$ \\
\hline
\end{tabular}

This analysis of the end dates of the vegetative period confirms, like before, the fact known from the literature, namely that vegetation "recedes" from the East towards the West and North of Poland.

The end dates of the vegetative period in the 68-year period considered varied in the lowland part of Poland between October $9^{\text {th }}$ (Suwałki -1946 
and 1976) and December $2^{\text {nd }}$ (Szczecin - 1951). Hence, the delay of the end date of vegetation in the West of Poland with respect to Suwałki may amount to 54 days (Fig. 1).

In the mountain areas the earliest date of the end of the vegetative period was noted in 1931 - in the last days of September (Zakopane September $29^{\text {th }}$ ), while the latest - in 1963 - in the second decade of November (Zakopane - November $17^{\text {th }}$ ).

Summing up, it can be stated that the end of the vegetative period in Poland can take place between the third decade of September and the first decade of December.

The analysis of the end dates of the vegetative period demonstrates also the significant deviation of the actual values from the long-term averages. Yet, the range of changes is not as big as in the case of the starting dates of the vegetative period. The amplitude of fluctuations of the end dates of the vegetative period in the lowland part of Poland is of the order of 30-40 days (Szczecin - 37 days, Łódź -41 days, Suwałki -37 days). The end of the vegetative period can take place by 15 to 20 days earlier than on the average, and by 19-22 days later than on the average. The range of variation of the end dates of the vegetative period in the mountains is about 50 days.

The analysis of frequency of appearance of the end dates of the vegetative period allows to state that they are less differentiated in time and space than the starting dates (see Fig. 3). It can be noticed that the vegetative period terminates most often in the $63^{\text {rd }}$ pentade of the year (November $7^{\text {th }}-11^{\text {th }}$ ) in western Poland, and in the $59^{\text {th }}$ pentade (October $18^{\text {th }}-22^{\text {nd }}$ ) and the $60^{\text {th }}$ pentade (October $23^{\text {rd }}-27^{\text {th }}$ ) in the north-eastern part of Poland and in the mountains. The terminal dates of the vegetative period are contained between the $59^{\text {th }}$ pentade (October $18^{\text {th }}-22^{\text {nd }}$ ) and the $68^{\text {th }}$ pentade (December $2^{\text {nd }}-6^{\text {th }}$ ) in the West of the country, and between the $57^{\text {th }}$ pentade (October $8^{\text {th }}-12^{\text {th }}$ ) and the $65^{\text {th }}$ pentade (November $17^{\text {th }}-21^{\text {st }}$ ) in the East of Poland.

\section{DURATION OF THE VEGETATIVE PERIOD}

The earlier start of vegetation in the western part of Poland and its earlier termination in the eastern part bear direct consequences on the length of the vegetative period (see Table 3). It varies between 190-200 days in the north-eastern part of Poland (Suwałki - 197 days) and about 230 days in the West of Poland (Szczecin, Wrocław - 230 days). A significant length of the vegetative period in the case of Szczecin is connected mainly with a large delay of the terminal date of this period. This is to an important degree due to the warming influence of the Baltic Sea in this time of the year. In the case of Wrocław the total length of the vegetative period must be linked with the fact that spring "enters" Poland from the South-West. This is an evidence for the domination of the oceanic influences over the continental ones over this area. 


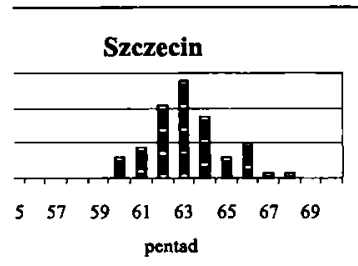

Gorz6w Wlkp.

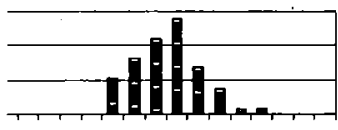

$\begin{array}{llllllll}5 & 57 & 59 & 61 & 63 & 65 & 67 & 69\end{array}$ pentad

Wroclaw

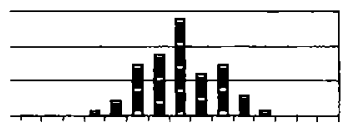

$\begin{array}{llllllll}5 & 57 & 59 & 61 & 63 & 65 & 67 & 69\end{array}$ pentad

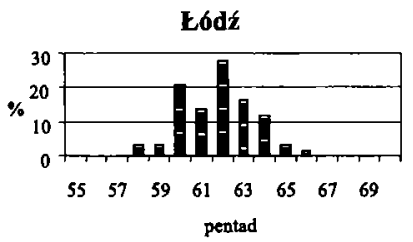

Kielce

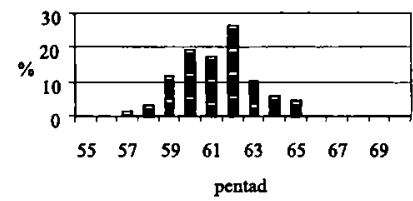

Zakopane

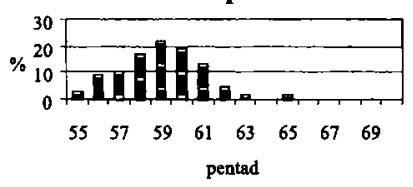

Suwalki

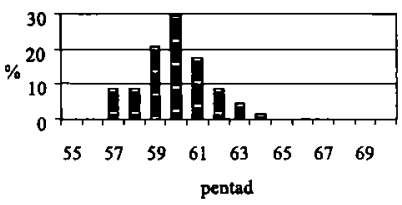

Siedlce

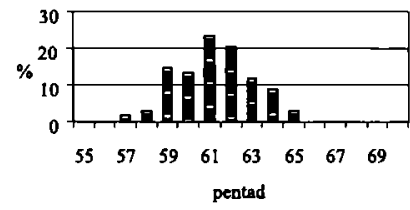

Tomasx6w Lub.

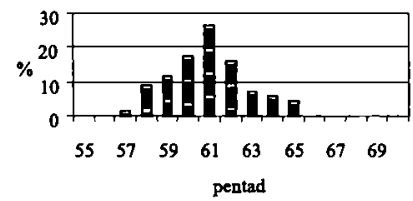

Fig. 3. Frequency $(\%)$ of the dates of the end of the vegetative period in the five-day intervals (1931-1998).

Table 3.

The average and the extreme dates of the length of the vegetative period (1931-1998)

\begin{tabular}{|l|c|l|c|}
\hline \multicolumn{1}{|c|}{ Locality } & Average & \multicolumn{1}{c|}{ Shortest } & Longest \\
\hline Szczecin & 230 & $198(1941)$ & $291(1990)$ \\
Suwałki & 197 & $170(1941)$ & $229(1990)$ \\
Gorzów Wielkopolski & 227 & $196(1956)$ & $277(1990)$ \\
Eódź & 217 & $188(1941)$ & $261(1990)$ \\
Siedlce & 211 & $188(1941)$ & $256(1990)$ \\
Wrocław & 230 & $205(1941,1956)$ & $280(1990)$ \\
Kielce & 213 & $185(1941,1997)$ & $245(1934)$ \\
Tomaszów Lubelski & 209 & $192(1997)$ & $246(1990)$ \\
Zakopane & 187 & $159(1931)$ & $221(1934)$ \\
\hline
\end{tabular}


In mountains, due to the latest beginning of the growing season and its earliest termination - the length of this period is the shortest within the whole area of Poland (Zakopane - 187 days).

Duration of the vegetation period, being a reflection of the thermal relations of the Polish climate, with its characteristic (specific) features, such as: intermediate nature, variability, and contrasts, undergoes significant changes from year to year. Hence, quotation of the average values does not provide the complete image of the course of thermal conditions in Poland with respect to plant development, and so these values ought rather to be considered as a background for this kind of considerations. The average values, namely, bring a definite fuzziness into the true image of changes, which are of interest for farmers, referring not only to the start and end of the growing season in the particular years, but also to its duration. And yet, these changes are often quite important.

The length of the vegetative period varies in the lowlands between 170 days (in Suwałki in 1941) and the 291 days of the absolute maximum (Szczecin in 1990). So, the range of variation is 121 days (Fig. 1). The length of the vegetative period in the mountains changes between 159 days (Zakopa- ne - 1931) and 221 days (Zakopane - 1934). The extreme values of the length of the vegetative period confirm the observation that this length in the lowland Poland decreases towards the East (the maximum duration of the vegetative period in Suwałki was 229 days in 1990), while in the mountains the duration is the shortest.

The changes of the starting and ending dates of the vegetative period determine the magnitude and the spatial differentiation of the length of duration of this period. The biggest range of variation in the length of the period of vegetation is observed in the North-West of Poland (93 days in Szczecin). On the remaining territory it takes values between 75 days in the south-western part to about 60 days in the East and in the mountains. This image is similar to the distribution of the average duration of the vegetative period, and thus - where the vegetative period is the longest, its variability is also the biggest. This is confirmed, as well, by the distribution of the frequency of the lengths of the growing season in the five-day intervals (Fig. 4). And thus, in Szczecin it lasts for at least 200 days, but not longer than 295 days, in Suwałki - between 170 and 230 days. In the areas with the longest duration of the vegetation period it most often lasts between 225 and 240 days, while there, where it is the shortest - in the lowlands between 195 and 220 days, and in the mountains - between 185 and 190 days.

The search for the relations between the starting and ending dates of the growing season on the one hand and its duration on the other (Table 4) made it possible to conclude that duration of the vegetative period is more strongly associated with the starting date than with the endpoint. This is presumably connected with the bigger year-to-year variability of the starting dates and the higher stability of the ending dates of the growing season. 


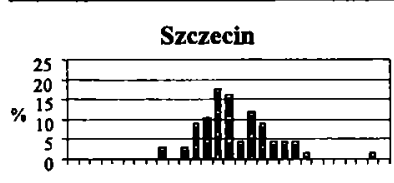

$\begin{array}{llllllll}160 & 180 & 200 & 220 & 240 & 260 & 280 & 300\end{array}$ number of days

Gorzow Wkp.

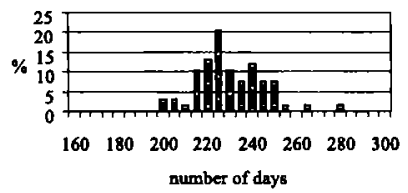

Wroclaw

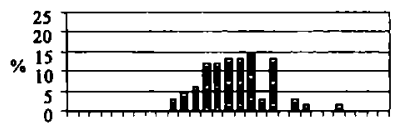

$\begin{array}{llllllll}160 & 180 & 200 & 220 & 240 & 260 & 280 & 300\end{array}$ number of days

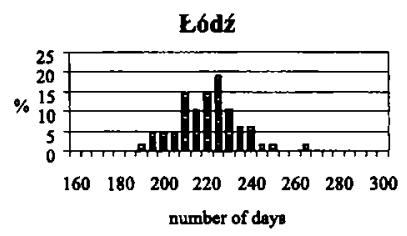

Kielce

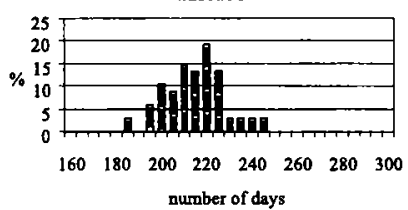

Zakopane

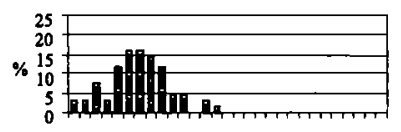

$\begin{array}{llllllll}160 & 180 & 200 & 220 & 240 & 260 & 280 & 300\end{array}$

number of days

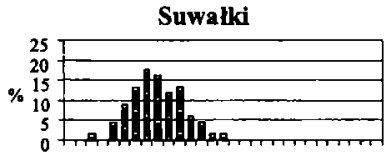

$\begin{array}{llllllll}160 & 180 & 200 & 220 & 240 & 260 & 280 & 300\end{array}$ number of days

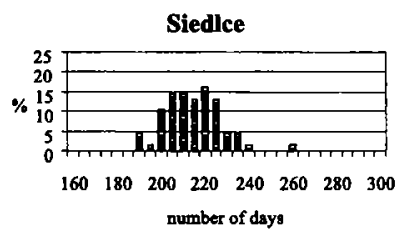

Tomaszow Lub.

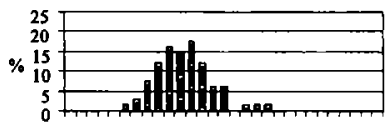

$\begin{array}{llllllll}160 & 180 & 200 & 220 & 240 & 260 & 280 & 300\end{array}$ number of days

Fig. 4. Frequency (\%) of the lengths of the vegetative period (1931-1998).

Table 4.

Coefficients of correlation between the dates of beginning/end of the vegetative period and its length

\begin{tabular}{|l|c|c|}
\hline \multicolumn{1}{|c|}{ Locality } & Beginning/length & End/length \\
\hline Szczecin & -0.85 & 0.61 \\
Suwałki & -0.72 & 0.75 \\
Gorzów Wielkopolski & -0.86 & 0.60 \\
Eódź & -0.79 & 0.64 \\
Siedlce & -0.74 & 0.69 \\
Wrocław & -0.82 & 0.65 \\
Kielce & -0.73 & 0.69 \\
Tomaszów Lubelski & -0.69 & 0.73 \\
Zakopane & -0.72 & 0.74 \\
\hline
\end{tabular}

Previous analyses (Olszewski, Żmudzka, 1997) of the year-to-year variability of the selected characteristics of the vegetative period indicated a weak trend in their changes. The equations of the (straight) regression lines for the period 1931-1990 indicated that the length of the vegetative period 
has been increasing at the rate of 1 to 3 days per 10 years. This was linked with the acceleration of the start of vegetation by approximately $0.5-1.5$ days per 10 years, and the delay of its termination also by $0.5-1.5$ days per 10 years. Such a result was most probably largely influenced by the last years of the period considered, which were warmer than usually. Presently, after the period analysed has been extended with consecutive years (19311998) the linear regression equations (Table 5) do not display any more such tendencies, in spite of the persisting high annual averages of temperature. One can still observe an acceleration of the starting date of the vegetative period, on the average by $0.5-1.5$ days per 10 years, but the terminal dates of the vegetative period do not undergo almost any change. That is why also the length of the vegetative period does not indicate, contrary to the previously considered period of analysis, the similar tendencies of prolongation.

Table 5.

Trends of changes of the beginning, end and length of the vegetative period (according to linear regression equation)

\begin{tabular}{|c|c|c|c|}
\hline Locality & Beginning & End & Length \\
\hline \multicolumn{4}{|c|}{ in days 10 years } \\
\hline Szczecin & -1.5 & 0.5 & 2.0 \\
\hline Suwałki & -0.4 & 0.1 & 0.5 \\
\hline Gorzów Wielkopolski & -1.1 & 0.0 & 1.1 \\
\hline Łódź & -1.4 & 0.0 & 1.4 \\
\hline Siedlce & -1.0 & 0.0 & 1.0 \\
\hline Wrocław & -0.9 & -0.5 & 0.5 \\
\hline Kielce & -0.6 & -0.4 & 0.2 \\
\hline Tomaszów Lubelski & -0.7 & -0.1 & 0.6 \\
\hline Zakopane & -0.1 & 0.8 & 0.9 \\
\hline
\end{tabular}

The spectra of oscillations of the length of the vegetative period in Poland contain the significant periodicity of 4.7 years and 7.7 years ( 7.7 years in western Poland and 7.9-8.0 years in eastern Poland). It is worth mentioning here that the 7.7-year-long cycle is the basic cycle of the variation of the monthly average air temperatures in Poland (Żmudzka, 1995). This particular periodicity appears also in the spectrum of oscillations of the seasonal values of temperature, especially in spring and in winter.

$$
\text { is is is }
$$

The above considerations confirmed the facts known from the literature, namely that in Poland the vegetative period starts on the average at the turn of April, and ends at the turn of November. It lasts, therefore, on the average, 190- 200 days in the north-eastern part of the country, and up to 230 days in the West, while in the mountains - approximately 185 days. 
There are, however, significant fluctuations from year to year in the starting and ending dates of the vegetative period. In the period analysed of 68 years in the lowland part of Poland the earliest starting date was January $29^{\text {th }}$ (in $1990)$, the latest one - April $25^{\text {th }}$ (1941, 1955). The terminal dates of the vegetative period varied between October $9^{\text {th }}(1946,1976)$ and December $2^{\text {nd }}$ (1951). The length of the vegetative period can vary between 170 days (in 1941) and 291 days (in 1990) — the latter being the absolute maximum for this period. It appears that this length is more strongly related to the starting date of vegetation than to its termination. The analysis of the periodical changes has shown that special attention ought to be paid to the cycle of 7.7 years in case of the starting dates of the vegetative period and to the cycle of approximately 4 years of length in case of the termination dates. The true length of the 7.7-year cycle of the beginning of the vegetative period is getting bigger along the line from the West (7.6 years) to the East (7.9 years). The periodical components (length of the period and amplitude of oscillations) for the termination date of the vegetative period, feature, on the other hand, high uniformity over the area of Poland. The cycles of approximately 4 years and 7.7 years are also significant cyclical components in the time series of duration lengths of the vegetative period. The linear regression equations indicate an acceleration of the starting date of the vegetative period by $0.5-1.5$ days per 10 years, while the changes of the termination date of the vegetative period are practically marginal.

\section{REFERENCES}

B ochenek Z., 1999, Operacyjne wykorzystanie zdjęć satelitarnych NOAA AVHRR do oceny warunków rozwoju upraw w Polsce [Operational use of the NOAA AVHRR satellite images in the assessment of crop raising conditions in Poland], Fotointerpretacja $w$ Geografii, 29, Warszawa.

B ory c zk a J., 1993, Naturalne $i$ antropogeniczne zmiany klimatu Ziemi $w$ XVII-XXI wiek $u$ [Natural and anthropogenic changes of the Earth's climate in the $17^{\text {th }}-21^{\text {st }}$ centuries], Wyd. Uniwersyteyu Warszawskiego, Warszawa.

Climate Variability, Agriculture and Forestry, 1994, Technical Note, No. 196, WMO, Geneva.

Dąbrowska-Zielińska K., 1999, Systemy wczesnego ostrzegania przed zagrożeniem występowania niedoborów wody na obszarach rolniczych na podstawie zdjęć satelitarnych NOAA [Early warning systems for the threat of appearance of water shortage in agricultural areas on the basis of the NOAA satellite images], Fotointerpretacja $w$ Geografii, 29, Warszawa.

Dulczewska E., 1989, Zmiany okresu wegetacyjnego w Polsce w latach 1931-1970 [Variation of the growing season in Poland in the years 1931-1970], M.A. thesis typescript in the Department of Climatology of the Faculty of Geography and Regional Studies, University of Warsaw, Warszawa.

Gu mińs ki R., 1950, Kurs meteorologii $i$ klimatologii [A course on meteorology and climatology], PZWS, Warszawa.

Merecki R., 1914, Klimatologia ziem polskich [Climatology of Polish lands], J. Cotty, Warszawa. 
Olszewski K., Żmudzka E., 1997, Zmiany okresu wegetacyjnego w Polsce [Changes in the growing season in Poland], Prace i Studia Geograficzne, 20, Warszawa.

R a d o m ski Cz., 1979, Agrometeorologia [Agrometeorology], PWN, Warszawa.

S ta rk el L., ed., 1991, Geografia Polski - środowisko przyrodnicze [Geography of Poland - natural environment]. PWN, Warszawa.

$\dot{\mathrm{Z}} \mathrm{mud} \mathrm{zk}$ a E., 1995, Tendencje i cykle zmian temperatury powietrza w Polsce w latach 1951-1990 [Air temperature change trends and cycles in Poland in the years 19511990], Przeglqd Geofizyczny, 2, Warszawa. 